\title{
The Effect of the Application of the Cooperative Learning Model Type: Team Games Tournament on Student Learning Outcomes in Economic Subject
}

\author{
Pupu Saeful Rahmat ${ }^{1}$, Agus Gunawan ${ }^{2}$, Fajar Anugrah Prasetio ${ }^{3}$ \\ ${ }^{123}$ Universitas Kuningan, Indonesia \\ \{1 pupu.saeful.rahmat@uniku.ac.id, ${ }^{2}$ agusgunawan2025@gmail.com, ${ }^{3}$ pajar.anugrah@uniku.ac.id\}
}

\begin{abstract}
This The problem in this study is the low student learning outcomes in economics subjects at SMA Negeri 2 Kuningan. This was shown from the test scores of class X-1 students for the academic year 2018-2019 on standard competency material to understanding of economic concepts in relation to the Economic Activities of Consumers and Producers of the 35 students of class X-1 SMA Negeri 2 Kuningan, there were 48.56 $\%$ of students who had grades below the KKM (Kriteria Ketuntasan Minimal)/(MCC=Minimum Completeness Criteria) or are declared not passing the material on consumer and producer behavior. The purpose of this study was to determine the effect of the application of the cooperative learning model type team games tournament to student learning outcomes in economic subjects with the research subjects of class X SMA Negeri 2 Kuningan. Class X-1 was chosen as the experimental class to be treated (treatment) and class X-2 as the control class or the comparison class which was treated with the conventional learning method. The research method used was a quasi-experimental method. The data was collected by means of a written test. Data processing was performed using parametric statistical tests through two-way independent $t$ test (indefendent $t$-test). Using the SPSS program for windows version 21.00. Based on the results of the research, there was an effect of the application of the cooperative learning model type team games tournament to student learning outcomes in economic subjects at the standard of Competence Understanding Economic Concepts in Relation to Consumer and Producer Economic activities at Class X Students of SMA Negeri 2 Kuningan. Its meaning that the TGT method is very effectively used to teach the concept of Economics in the material of Consumer and Producer Economic activities at Class X SMA Negeri 2 Kuningan. Suggestions that can be conveyed are for teachers who will teach the economic concept of material economic activities of Consumers and Producers, it would be better if they try to use the TGT method, because through the research conducted by us as researchers it turns out that the TGT method is effective in teaching material for consumer and producer activities.
\end{abstract}

Keywords: cooperative learning model; learning type team game tournaments; learning outcomes

\section{Introduction}

The development of the world of education today demands the creativity of all components in the field of education [1]. Various new breakthroughs continue to be made by the government through the Ministry of Education and Culture. [2] These efforts include school management, increasing educational resources, developing/writing teaching materials, and 
developing new paradigms with teaching methodologies. The government's effort in education is to perfect the 2013 Curriculum (Kurtilas) in a more effective and fun juxtaposition. [4 ] This curriculum requires teachers to be more patient, attentive and understanding, and have creativity and dedication to foster students' self-confidence. [3]

In the implementation of education, must pay attention to the objectives of implementing education. The aim of Indonesia's national education is to "develop the potential of students to become human beings who believe in and fear the Almighty God, have noble character, are healthy, knowledgeable, are capable of being independent and become democratic and responsible citizens" (Chapter II Article 3 of the Law RI No. 20 of 2003). [4] In order to realize the educational goals set forth in the national education system, all components of education must be able to function optimally. [3]

One of these components is the learning model used by a teacher. The presentation of the material is expected to improve the ability of teachers to solve various problems that often arise in learning. In implementing learning, the hope is that the teacher can carry out studentcentered learning with an active, creative, effective, and fun learning approach using a variety of methods. [5] With the implementation of this learning, it is hoped that it can fulfill the goals and ideals of national education. Student-centered learning is expected not only to be able to equip students to remember the material being studied, but also to be able to solve problems faced in the long term. [6] [7] But in fact, what teachers often do in their learning model is a conventional learning model followed by assignments. [8]

This is considered to be unable to explore the potential and thinking patterns of students, because the material presented is limited to mastery of the material[5]. In direct learning, the most active thing in the learning and teaching process is the teacher, while students are only passive listeners and take notes on the subject matter delivered by the teacher. This resulted in teaching and learning activities that were still focused on teachers and did not involve student participation. To see the success of an educational process, it can be seen from the achievements or learning outcomes of students. [9] Assessment of success or failure of students in learning is not only based on numerical assessments, but far from this numerical assessment, changes in student behavior patterns towards the better indicate that students have succeeded in the learning process. However, learning achievement at school is always associated with daily learning outcomes at school, to determine learning achievement at school, namely by looking at the actualization of learning activities, one of which is in the form of results from the learning achievements that they get[12].

So far there are still problems in learning, teachers only focus on the target curriculum achievement, lack of realizing interaction between students and understanding learning to be able to understand the meaning of learning materials, resulting in low student learning outcomes. [10] Cases like this happened in SMA Negeri 2 Kuningan, where teachers still mostly use direct learning models with teacher-centered approaches that result in poor student learning outcomes. This can be seen through the results of the X-1 grade students' test results at SMA Negeri 2 Kuningan in the 2019-2020 academic year in the pre-research which results are as follows: Of the 35 students tested, the scores obtained by the X-1 grade students of SMA N 2 Kuningan in the 2019-2020 school year there are still those that are under the minimum completeness criteria (KKM) of competency standards with a class average score of 65.42 while the school's KKM score is 70 . In this test $48.56 \%$ of students had a under the KMM or stated that they did not pass the consumer and producer behavior material, the number of students who passed was $51,426 \%$. This shows that there is a problem that results in many X-1 class students of SMAN 2 Kuningan whose learning outcomes are low in 
economic subjects. This also shows that there are problems with student learning outcomes on consumer and producer behavior in class X-1 SMA Negeri 2 Kuningan.

The root of the problem identified is the delivery of subject matter that is only given in nature, therefore it is necessary to develop a learning model that is possible, namely by sharing knowledge between peers and between students and teachers. Students need to be given the opportunity to learn intractively and collaborate with friends in improving learning outcomes. One solution in overcoming the direct learning method is the team games tournament learning model, this learning model can help students develop, analyze, and solve problems and can help students develop their opinions and thinking skills. [13]

Based on the problems that have been stated above, the formulation of the problems to be studied are as follows:

a. Are there differences in student learning outcomes in the control group using conventional learning models when compared to the pre-test and the post-test?

b. Are there differences in student learning outcomes in the experimental group using cooperative learning type Team games tournament when compared at the beginning (pretest) and at the end (post-test).

c. Are there differences in student learning outcomes in the experimental group who use cooperative learning type Team games tournament after being given treatment with student learning outcomes in the control group using conventional learning models?

\section{Team Games Tournament Learning Method}

Teams Games Tournament (TGT), originally developed by David Devries and Keith Edwards, [13] this method is Johns Hopkins' first learning method. According to Rusman, [8] Team games tournament or TGT is a type of cooperative learning that places students in study groups consisting of 5 to 6 people who have different abilities, gender, and syllables or races". The teacher presents the material, and students work in their respective groups. In group work, the teacher gives worksheets to each group. The assigned task is done together with the group members. [14]. Based on what was expressed by Slavin, the TGT type of cooperative learning model has the following characteristics: [6].

a. Students work in small groups

b. Games tournament

c. Group awards

The TGT type of cooperative learning is one of the cooperative learning models [ 8] that is easy to apply, involves the activities of all students without having any difference in status, involves the role of students as peer tutors and contains elements of play. Learning activities with games designed in the TGT type of cooperative learning allow students to learn to be more relaxed in addition to fostering responsibility, cooperation, games, competition, health and learning involvement.

According to Slavin in implementing the TGT type of cooperative learning model, there are several stages that need to be taken, namely: [6]
a. Teach
b. Study Group (team study)
c. Games (games tournament)
d. Team recognition

The Team Games Tournament (TGT) cooperative learning method has advantages and disadvantages. According to Sudjana [11] the advantages of TGT learning include:

a. Further increase the time spent on assignments

b. Promoting acceptance of individual differences 
c. With a little time can master the material in depth

d. The teaching and learning process takes place with the activeness of students

e. Educating students to practice socializing with others

f. Higher learning motivation

g. Better learning outcomes

h. Increase kindness, sensitivity and tolerance

While the weaknesses of TGT are: [6]

a. For teachers the difficulty of grouping students who have heterogeneous abilities from an academic perspective. This weakness will be overcome if the teacher who acts as the holder of the control is careful in determining the division of the group. This difficulty can be overcome if the teacher is able to master the class as a whole

b. For students There are still high-ability students who are not used to it and find it difficult to provide explanations to other students. To overcome this weakness, the teacher's job is to properly guide students who have high academic abilities so that they can and are able to pass on their knowledge to other students.

\title{
Learning outcomes
}

Learning is a relatively constant process of changing behavior. In this process, change does not happen all at once but occurs gradually depending on the learning support factors that affect students. Learning will always be related to learning outcomes. Learning outcomes are something that students achieve or obtain thanks to their efforts or thoughts, which is expressed in the form of mastery, knowledge and basic skills found in various aspects of life so that it appears in the individual a relatively constant change in behavior.

In line with this, learning outcomes are a description of the ability of students to fulfill a stage of achieving learning experiences in one basic competency" [9]. Learning outcomes are used by teachers to be used as a measure or criterion in achieving an educational goal. [11]. This can be achieved when students understand learning accompanied by changes in behavior for the better. To find out whether the learning outcomes that have been carried out have achieved and are in accordance with the desired objectives, [14] It can be seen through learning evaluation. This is in line with Kulsum's opinion [7] that evaluation is a process of giving consideration to the value and meaning of something being considered (evaluated).

Something that is considered can be a person, object, activity, situation, or a certain entity. In learning there are several factors that can influence students. A person's success or failure in learning is caused by factors that come from within the individual and factors from outside the individual. The factors that influence learning outcomes are: [10]

\section{Internal factors}

\author{
a. Physical (health, disability) \\ b. Psychological (intelligence, attention, interests, talents, motives, maturity, readiness) \\ c. Fatigue

\section{External factors}

a. Family (how parents educate, relations between family members, home atmosphere, economic situation, family, understanding of parents, cultural background).

b. School (teaching methods, curriculum, teacher-student relations, student-student relations, school discipline, learning tools, school time, lesson standards, building conditions, learning methods, homework).

c. Society (student activities in society, mass media, social friends, forms of community life. 


\section{Methodology}

The object of this research is student learning outcomes through the application of the team games tournament learning model. [14] Through pre-research, Class X-1 was selected as an experimental class for treatment and class X-2 as a control class or comparison class for which treatment was carried out through conventional lecture learning methods. The subjects in this study were students of class X at SMA Negeri 2 Kuningan.

The method used in this research is a quasi-experimental method. [12] In this study, the team games tournament type cooperative learning model was given to the experimental group and the conventional learning model to the control group. After determining the research method, then making a research plan or design as outlined in the research design. Research design is a plan or design made by the researcher, as a square for activities to be carried out. The experimental pattern used in this research design was the pre-test post-test control group design. The pattern is carried out as follows:

Table 1. Research Design

\begin{tabular}{cccc}
\hline Group & Pre-test & Treatment & Post-test \\
\hline Experiment & $0_{1}$ & $\mathrm{X}_{1}$ & $0_{3}$ \\
Control & $0_{2}$ & - & $0_{4}$ \\
\hline
\end{tabular}

X1: $\quad$ Subject to treatment or treatment through the learning process by using the Team type cooperative learning model games tournament

: $\quad$ no treatment

01: $\quad$ Pre-test (before treatment) in group experiment

02: $\quad$ pre-test (before treatment) in control group

03: final test / post-test (after treatment) in the group experiment

04: final test / post-test (after treatment) in the control group

This research was conducted in 2 classes, namely the first class that was treated using the type of team games tournament (experimental class) and the second class was not given any treatment (control class). The design development in this study was carried out by making a difference in one test before doing the treatment which is also called the pre-test, then after doing the pre-test, another measurement (post-test) is carried out. The pre-test in this research design can also be used as a statistical control (statistical control), and can also be used to see how the effect of the treatment on the score achieved (gain score).

This research was conducted in 2 classes, namely the first class that was treated using the type of team games tournament (experimental class) and the second class was not given any treatment (control class). The design development in this study was carried out by making a difference in one test before doing the treatment which is also called the pre-test, then after doing the pre-test, another measurement (post-test) is carried out. The pre-test in this research design can also be used as a statistical control (statistical control), and can also be used to see how the effect of the treatment on the score achieved (gain score).

In conducting research, the instruments used in this study were tested by means of test tests. In this study, the test was used twice, namely the pre-test and the post-test. The pre-test was carried out at the beginning of the study. It was carried out to determine the students' prior knowledge before the cooperative learning process was carried out with the team games tournament type. The post-test or final test is carried out at the end of the study with the aim of knowing and measuring student learning outcomes after implementing the cooperative learning process with the team game tournament type. To collect data on student learning 
outcomes in economic subjects, the subject of Economic Concepts in Relation to Consumer and Producer Economic Activities. [17]. The test used is a multiple choice test by selecting one of several possible answers that have been provided about the material. The hypothesis test used in this study is a parametric statistical test through a two-way independent $t$ test (independent t-test). If the test data for learning outcomes are normally distributed and homogeneous, then to examine the hypothesis, parametric statistics are used, namely the independent t-test according to the following formula:

$$
\mathrm{t}=\frac{M_{1}-M_{2}}{\sqrt{\left\{\frac{\Sigma x^{2} \Sigma y^{2}}{N_{x}+N_{y}-2}\right\}\left\{\frac{1}{N_{x}}+\frac{1}{N_{y}}\right\}}}
$$

Description

$\mathrm{M}=$ the average value of the results per group

$\mathrm{N}=$ Number of students

$\mathrm{X}=$ the deviation of each value of $\mathrm{X} 1$ and $\mathrm{X} 2$

$\mathrm{y}=$ the deviation of each of the Y1 and Y2 values

The results obtained were consulted on the $t$ distribution table for the two-way test.

\section{Result and Discussion}

The first hypothesis states that there are differences in student learning outcomes in the control group using conventional learning models when compared at the beginning (pre-test) and at the end (post-test). [16] The data used for this first hypothesis is the data from the pretest and post-test results of control class students by implementing conventional learning methods. By using SPSS version 21.00, the hypothesis test for the first hypothesis is as follows:

Table 2. Hypothesis Results Data Pre-test and Post-test Control class Paired Samples Test

\begin{tabular}{|c|c|c|c|c|c|c|c|c|c|}
\hline & & \multicolumn{5}{|c|}{ Paired Differences } & \multirow[b]{3}{*}{$\mathrm{t}$} & \multirow[b]{3}{*}{ df } & \multirow{3}{*}{$\begin{array}{l}\text { Sig. (2- } \\
\text { tailed) }\end{array}$} \\
\hline & & \multirow[b]{2}{*}{ Mean } & \multirow{2}{*}{$\begin{array}{c}\text { Std. } \\
\text { Deviation }\end{array}$} & \multirow{2}{*}{$\begin{array}{l}\text { Std. Error } \\
\text { Mean }\end{array}$} & \multicolumn{2}{|c|}{$\begin{array}{l}5 \% \text { Confidence Interval } \\
\text { of the Difference }\end{array}$} & & & \\
\hline & & & & & Lower & Upper & & & \\
\hline Pair 1 & $\begin{array}{l}\text { Post-test } \\
\text { control - } \\
\text { pre-test } \\
\text { control }\end{array}$ & 6.87500 & 3.05662 & .48329 & 5.89744 & 7.85256 & 14.225 & 39 & .000 \\
\hline
\end{tabular}

Source: SPSS 21.00 processing data

Based on the table above, it can be seen that the t test calculation on the pre-test and posttest scores of the control class students obtained the value of $\mathrm{t}=14,225$ for $\mathrm{df}=39$, obtained $\mathrm{t}$ table $=2.022$. Because tcount $>$ ttable, then Ho is rejected and H1 is accepted, it means that there are differences in student learning outcomes in the control group using conventional learning models when compared at the beginning (pre-test) and at the end (post-test).

The second hypothesis states that there are differences in student learning outcomes in the experimental group using cooperative learning type Team games tournament when compared at the beginning (pre-test) and at the end (post-test). The data used for this second hypothesis 
is the pre-test and post-test results of the experimental class students by implementing the team games tournament learning method. By using SPSS version 21.0, the hypothesis test for the second hypothesis is as follows:

Table 3. Hypothesis Results Data Pre-test and Post-test Experiment class

\begin{tabular}{|c|c|c|c|c|c|c|c|c|c|}
\hline \multicolumn{10}{|c|}{ Paired Samples Test } \\
\hline & & \multicolumn{5}{|c|}{ Paired Differences } & \multirow{4}{*}{$\begin{array}{c}\mathrm{t} \\
18.653\end{array}$} & \multirow{4}{*}{$\begin{array}{l}\text { df } \\
39\end{array}$} & \multirow{4}{*}{$\begin{array}{l}\text { Sig. (2- } \\
\text { tailed) } \\
.000\end{array}$} \\
\hline & & & Std. & $\begin{array}{l}\text { Std. } \\
\text { Error }\end{array}$ & $\begin{array}{r}95 \% \text { Confid } \\
\text { of the D }\end{array}$ & $\begin{array}{l}\text { ce Interval } \\
\text { erence }\end{array}$ & & & \\
\hline & & Mean & Deviation & Mean & Lower & Upper & & & \\
\hline Pair 1 & $\begin{array}{l}\text { Post-test } \\
\text { experiment - } \\
\text { pre-test } \\
\text { experiment }\end{array}$ & 9.950 & 3.37373 & .53343 & 8.87103 & 11.02897 & & & \\
\hline
\end{tabular}

Based on the table above, it can be seen that the t-test calculation on the pre-test and posttest scores of the experimental class students obtained the value of $\mathrm{t}=18,653$ for $\mathrm{df}=39$, obtained t table $=2.022$. Because tcount $>$ ttable, then Ho is rejected and H1 is accepted, it means that there are differences in student learning outcomes in the experimental group using cooperative learning type Team games tournament when compared at the beginning (pre-test) and at the end (post-test). The third hypothesis states that there are differences in the learning outcomes of the experimental group students who use cooperative learning type Team games tournament after being given treatment with the learning outcomes of students in the control group using conventional learning models. The data used for this third hypothesis is the NGain score data of the experimental class students and the N-Gain data of the control group students. By using SPSS 24.0, the hypothesis testing for the third hypothesis is as follows:

Table 4. Hypothesis Results of N-gain Data for Experiment Class and Control Class t-test for Equality of Means

\begin{tabular}{r|r|r|r|r}
\hline \multicolumn{1}{l|}{ T } & df & Sig. (2-tailed) & Mean Difference & Std. Error Difference \\
6.815 & 78 & .000 & .23650 & .03470 \\
6.815 & 75.344 & .000 & .23650 & .03470 \\
\hline
\end{tabular}

Based on the formula and analysis criteria contained in chapter III, from the table above, it can be seen that the results of the $\mathrm{t}$ test calculation on the $\mathrm{N}$-gain value of the control class and the experimental class obtained the value of tcount $=6.815$ for $\mathrm{df}=78$, obtained $\neg$ table $=1.99$ means that $\mathrm{t}$ table, then Ho is rejected, or from the calculation of $\alpha=5 \%$, which is 0.05 , the two remaining rejection can be concluded that Ho is unacceptable because the two-sided significance $0.00<0.05$ significant level $(\alpha)$ means that there are differences in student learning outcomes. Experiment using cooperative learning type Team games tournament with student learning outcomes control group using conventional learning models

The variable examined in this study is the cooperative learning model type Team Games Tournament as the independent variable (X), while the dependent variable (Y) in this study is student learning outcomes in economic subjects. Learning outcomes are something that is achieved or obtained by students thanks to their efforts or thoughts, which is expressed in the form of mastery, knowledge and basic skills found in various aspects of life so that it appears in individuals relatively constant changes in behavior. In this study, the team games tournament type cooperative learning model was given to the experimental group and conventional learning models to the control group. Team games tournament is a learning 
method in the cooperative learning model, which places students into several groups with different (heterogeneous) student classifications which include the stages of teaching teaching presentations by teachers, group learning or discussions, organizing games, tournaments, and awarding groups in the learning process.

Based on the results of research that has been conducted by researchers at SMA Negeri 2 Kuningan with class X SMA as research subjects. Based on the results of the statistical study after being given the material, the experimental group was subjected to treatment in the form of the Team games tournament learning model and the control group using the conventional learning model. The average student learning outcomes of the experimental group after being subjected to the team games tournament learning model were higher, namely 83.5 compared to the average control group after using the conventional learning model, which was 68.5.

From the results of the first hypothesis statistical calculations for the $t$ test on the pre-test and post-test scores of the control class students, the value of tcount $=14,225$ for $\mathrm{df}=39$, obtained t table $=2.022$. Because tcount $>$ ttable, then Ho is rejected and H1 is accepted, it means that there are differences in student learning outcomes in the control group using conventional learning models when compared at the beginning (pre-test) and at the end (posttest). In the second hypothesis t-test calculations on the pre-test and post-test values of the experimental class students obtained the value of $\mathrm{t}=18,653$ for $\mathrm{df}=39$, obtained $\mathrm{t}$ table $=$ 2.022. Because tcount> ttable, then Ho is rejected and $\mathrm{H} 1$ is accepted, meaning that there is a difference in student learning outcomes in the experimental group using cooperative learning type Team games tournament when compared at the beginning (pre-test) and at the end (posttest). In the $t$ test results of the two classes, both the control class and the experimental class proved that the two learning methods obtained differences before learning and after learning.

The third hypothesis is that the statistical calculations for the $t$ test are taken based on the data on the magnitude of the N-Gain score. The N-Gain data is obtained from the results of calculations using data from the pre-test and post-test, the N-Gain data shows an increase in the ability of students after participating in learning both using the team games tournament method and conventional methods. based on the statistical test results of the $t$ test calculation on the $\mathrm{N}$-gain value of the control class and the experimental class, the value of tcount $=6.815$ for $\mathrm{df}=78$, obtained $\neg$ table $=1.99$ means that tcount $>$ ttable, then Ho is rejected, or from the calculation $\alpha=5 \%$ that is 0.05 , the two remaining rejections can be concluded that Ho cannot be accepted because the two-sided significance $0.00<0.05$ significant level $(\alpha)$ means that there are differences in student learning outcomes in the experimental group using cooperative learning type Team games tournament with student learning outcomes control group using conventional learning models.

The increase in student learning outcomes (N-Gain) in the experimental class was higher than the control class. The average gain score for the control class was 34.37, while the average gain score for the experiment was 49.75 . It can be concluded that the team games tournament learning model will improve student learning outcomes. The team games tournament type cooperative learning method invites students to study in one group which invites students to be more active, creative, effective, and fun. [11] By holding competitions between groups made in a game, students are more enthusiastic about learning because they feel like winning the game. With enthusiasm in participating in the game, it can make students more enthusiastic in learning the material. The cooperative method of the team games tournament type makes all students actively seek the knowledge they have from others, so that each student can better master the material. This is in line with the opinion of Slavin. [6]. The team games tournament learning method adds a dimension of joy obtained from the use of games. Learning activities with games designed in the TGT model of cooperative learning 
allow students to learn to be more relaxed in addition to fostering responsibility, cooperation, healthy competition, and learning involvement. [13]

With the cooperation between group members, it can lead to conceptual changes, students' minds and thoughts can develop so that it will foster student interest in learning which can improve student learning outcomes. [16] [11] Therefore, the team games tournament learning model can be a solution to explore knowledge, potential for student thinking and work, increase understanding of concepts, and can apply learning materials which will later have an effect on improving student learning outcomes [13]. In addition to the above opinion, the results of this study are in line with previous research by Andika Nurhidayat (2009) with the results of his research which states that the application of the cooperative learning model type team games tournament has a positive effect on student learning outcomes. This study states that the existence of games in the team games tournament learning model makes students more enthusiastic and happy in participating in the learning process which results in a good influence on improving student learning outcomes. The findings of another study conducted by Selviana Jufri (2009) The results of this study indicate that the learning interest of students who take part in learning using the TGT type of cooperative method is higher than students who take lessons using the lecture method. With an increase in student interest in learning, it has an effect on improving student learning outcomes.

So, the economic learning outcomes of students who take lessons using the Team Games tournament method are higher than the economic learning outcomes of students who take learning using conventional methods. [10] The explanation of this concept has been proven in the research results for three meetings using the team games tournament learning model in the experimental class and comparing it with the class that does not use the team games tournament learning method, namely the control class. The results showed that the team games tournament learning model could improve student learning outcomes by imposing pre-test and post-test as a measuring tool for improving student learning outcomes. Thus it can be concluded that there is an effect of the application of the cooperative learning model type team games tournament on student learning outcomes in economic subjects. The results of the study show that it is significant or in accordance with the theory previously stated.

\section{Conclusion}

Based on the results of research and hypothesis testing using the team games tournament learning model, the following conclusions can be drawn:

a. There are differences in student learning outcomes in the control group using conventional learning models when compared at the beginning (pre-test) and at the end (post-test).

b. There are differences in student learning outcomes in the experimental group using cooperative learning type Team games tournament when compared at the beginning (pretest) and at the end (post-test).

c. There are differences in student learning outcomes in the experimental group who use cooperative learning type Team games tournament after being given treatment with student learning outcomes in the control group using conventional learning models. 


\subsection{Suggestion}

Based on the results of the research and the conclusions written in the previous section, after observing the student's condition and learning conditions, the application of the team games tournament learning model has been proven to improve student learning outcomes in economic subjects, which means that this method is very suitable for teachers to implement. the process of teaching and learning activities. Therefore, there are several suggestions that need to be considered, namely:

a. For Teachers

Teachers in the field of economic studies should be able to try economic learning using the team games tournament learning model as a learning model that can make students more active, creative, effective, and enjoyable in the learning process.

b. For the school

Schools are expected to contribute to economic learning for their schools. Schools are expected to provide equipment and facilities that will be used by teachers in carrying out the learning process to improve the quality of learning at school.

c. For further researchers

For other researchers, it is hoped that they can be more creative in preparing good and mature learning plans. So that the implementation can run well and get maximum results.

\section{References}

[1] Rahmat, Pupu Saeful. Teaching Learningb Strategies..Surabaya: Scopindo.2019

[2] Depdiknas. Contextual Approach. Depdiknas. PLP Directorat. 2002.

[3] Suwandi. Development of the Islamic Religious Education Curriculum in Higher Education: Surabaya: UIN Sunankalijaga.2016

[4] Ministry of Education and Culture Republic of Indonesia. Law No. 20 of 2003 concerning the National Education System.

[5] Budiwati Neti and Leni Permana.Economic Learning Planning. 2010.

[6] Slavin, E. Robert. Cooperative Learning. Bandung: Nusa Media Publishers. 2009. 13-14).

[7] Kulsum, Umi. Contextual Approach (Contextual Teaching and Learning (CTL). Jakarta: Ministry of National Education, Dikdasmen. 2002

[8] Rusman. Learning Models Developing Professionalism Teacher. Jakarta: Rajawali Press. 2012

[9] Sanjaya, Viena. Learning in Curriculum-Based Implementation Competence. Jakarta: Golden. 2006.

[10] Slameto. Learning and Affecting Factors. Jakarta: Rineka Cipta. 2010

[11] Sudjana, Nana. Assessment of Teaching and Learning Process Results. Bandung: PT

[12] Youth Rosda Karya. 2009.

[13] Sugiyono. Educational Research Methods, Quantitative Approaches, Qualitative and R \& D. Bandung: Alfabeta. 2010. Page 77-79

[14] Selviana, Jufri. (2009). Effectiveness of Application of Games Type Learning Method Tournament (TGT) on student interest and achievement in the eyes chemistry class X semester 3 MAN Wonokromo Bantul year 2008/2009 teaching. Thesis: chemistry education.

[15] Sagala, Syaiful. Professional Capabilities of Teachers and Education Personnel. Bandung: Alfabeta. 2009.

[16] Arikunto, Suharsimi. Research Management. Jakarta: Rineka Cipta. 2007

[17] Neti Budiwati and Leni Permana. Planning for Economic learning. Bandung: Economic and Cooperative Laboratory. 2010. 